\title{
Biological Activity of Quinoline Alkaloids from Raulinoa echinata and X-ray Structure of Flindersiamine
}

\author{
Maique W. Biavatti ${ }^{a \#}$, Paulo C. Vieira ${ }^{a *}$, M. Fátima das G. F. da Silva ${ }^{a}$, João B. Fernandes ${ }^{a}$, \\ Sandra R. Victor ${ }^{b}$, Fernando C. Pagnocca ${ }^{b}$, Sérgio Albuquerque ${ }^{c}$, Ignez Caracelli ${ }^{a}$ and \\ Julio Zukerman-Schpector ${ }^{\text {a,d* }}$
}

\author{
${ }^{a}$ Departamento de Química, Universidade Federal de São Carlos, CP 676, 13565-905, São Carlos - SP, Brazil \\ ${ }^{b}$ Centro de Estudos de Insetos Sociais, Universidade Estadual Paulista, Rio Claro - SP, Brazil \\ ${ }^{c}$ Faculdade de Ciências Farmacêuticas, Universidade de São Paulo, Av. do Café s/n, 14040-903, \\ Ribeirão Preto - SP, Brazil \\ ${ }^{d}$ Instituto de Química, Universidade de São Paulo, CP 26077, 05513-970, São Paulo - SP, Brazil
}

\begin{abstract}
A investigação fitoquímica dos extratos de caules e folhas da espécie endêmica Raulinoa echinata Cowan, Rutaceae, levou ao isolamento de alcalóides furoquinolínicos (esquimianina, kokusaginina, maculina e flindersiamina) e quinolônicos (1-metil-2-n-nonil-4-quinolona, 2- $n$ nonil-4-quinolona e 2-fenil-1-metil-4-quinolona). Os alcalóides isolados mostraram atividade antifúngica contra Leucoagaricus gongylophorus, o fungo simbionte de formigas cortadeiras (Atta spp). Quando testados in vitro contra formas tripomastigotas de Trypanosoma cruzi, os alcalóides foram inativos ou parcialmente ativos. Neste trabalho descrevem-se o isolamento dos alcalóides, a elucidação estrutural dos alcalóides quinolônicos e a estrutura obtida por difração de raio-X da flindersiamina, juntamente com os resultados dos bioensaios realizados.
\end{abstract}

Phytochemical survey of stems and leaves extracts of the South Brazilian endemic plant Raulinoa echinata Cowan, Rutaceae, led to the isolation of known furoquinoline alkaloids: the widespread skimmianine; kokusaginine, maculine, flindersiamine, and also quinolone derivatives: 1-methyl-2-n-nonyl-4-quinolone, 2-n-nonyl-4-quinolone and 1-methyl-2-phenyl-4-quinolone. These alkaloids showed antifungal activity against Leucoagaricus gongylophorus; the symbiotic fungus of leaf-cutting ants (Atta sexdens). They were inactive or displayed weak inhibitory activity when assayed in vitro against trypomastigote forms of Trypanosoma cruzi. In this paper, the isolation, structure elucidation and bioactivity results of these compounds are reported together with the X-ray structure of flindersiamine.

Keywords: Raulinoa echinata, furoquinoline and quinolone alkaloids, antifungal, Trypanosoma cruzi, X-ray structure determination

\section{Introduction}

Raulinoa is a monospecific genus and the species Raulinoa echinata Cowan (Rutaceae) is endemic in the Itajaí Valley, SC, Brazil. ${ }^{1}$ This perennial woody shrub is characterized by the presence of spines and has only been found in a short interval $(1000 \mathrm{~m})$ on the frequently inundated banks of Itajaí river in an approximate altitude of $100 \mathrm{~m}$, showing a high degree of adaptation to the environment.

\footnotetext{
* e-mail: paulo@dq.ufscar.br (chemistry);*e-mail: julio@dq.ufscar.br (X-ray crystallography); \# Permanent address: Universidade do Vale do Itajaí, Curso de Farmácia, CP 360, 88303-202, Itajaí - SC, Brazil
}

We have recently reported the isolation and biological activities of some compounds of $R$. echinata. ${ }^{2}$ In continuation of our search for trypanocidal compounds and natural products to be used in the control of leaf-cutting ants, we have investigated the methanol extracts of stems and leaves of $R$. echinata leading to the isolation of typical rutaceous furoquinoline alkaloids: the widespread skimmianine (1), kokusaginine (2), maculine (3), flindersiamine (4) and also the quinolone derivatives: $2-n$ nonyl-4-quinolone (5), 1-methyl-2-n-nonyl-4-quinolone (6) and 1-methyl-2-phenyl-quinolone(7).

Leaf-cutting ants are one of the most serious agricultural pests in South American countries and the biological control 
of these insects has been the aim of many studies. Their control can be achieved by inhibiting the growth of their symbiotic fungus.

Trypanocidal compounds are important for the treatment of Chagas' disease which is responsible for a considerable number of deaths in Central and South American countries.

In this paper we describe the isolation, structural determination and evaluation of the activity of furoquinoline alkaloids as inhibitors of the growth of the symbiotic fungus Leucoagaricus gongylophorus of leafcutting ants. The alkaloids were also assayed in vitro against trypomastigote forms of Trypanosoma cruzi.

\section{Experimental}

\section{General experimental procedures}

NMR spectra: a Bruker DRX-400 spectrometer, operating at $400.13 \mathrm{MHz}$ for ${ }^{1} \mathrm{H}$ and $100.62 \mathrm{MHz}$ for ${ }^{13} \mathrm{C}$ was used. All spectra were run in $\mathrm{CDCl}_{3}$ using TMS as internal standard. For GC-MS analysis was used a Shimadzu GC-17 A gas chromatograph fitted with a fused silica DB-1 ( $30 \mathrm{~m}$ x $0.25 \mathrm{~mm}$ i.d. $\times 0.25 \mu \mathrm{m}$ film thickness) capillary column, with helium as the carrier gas at a flow rate of $2.6 \mathrm{~mL} \cdot \mathrm{min}^{-1}$. The temperature was programmed initially at $70{ }^{\circ} \mathrm{C}$ for $1 \mathrm{~min}$, then increased with a rate of $10^{\circ} \mathrm{C} \cdot \mathrm{min}^{-1}$ to $280{ }^{\circ} \mathrm{C}$ and kept for $15 \mathrm{~min}$. The injection volume was $1 \mu \mathrm{L}$ in a split mode and temperatures of the detector/injector were $300{ }^{\circ} \mathrm{C} / 280{ }^{\circ} \mathrm{C}$ respectively. The chromatograph was coupled to a Shimadzu QP5000 mass selective detector at $70 \mathrm{eV}$ with scans from 50 to $500 \mathrm{amu}$.

$\mathrm{X}$-ray crystallographic data were recorded on an EnrafNonuis CAD-4 diffractometer using graphite monochromated $\mathrm{MoK} \alpha$ radiation $(\lambda=0.71073 \AA)$ and $\omega / 2 \theta$ scan mode at room temperature $(291 \mathrm{~K})$. During data collection, the intensity of three standard reflections were monitored every $30 \mathrm{~min}$ of $\mathrm{X}$-ray exposure time showing no significant decay. Direct Methods solved the structure. $\mathrm{H}$ atoms were placed in calculated positions with fixed $\mathrm{C}-\mathrm{H}$ distances ( $0.93 \AA$ for Csp 2 and $0.96 \AA$ for Csp3), each riding on a carrier atom with isotropic displacement parameters amounting to 1.5 (for methyl $\mathrm{H}$ atoms) or 1.2 (for the other $\mathrm{H}$ atoms) times the value of the equivalent isotropic displacement parameter of the carrier atom. The CAD-4 Software ${ }^{3}$ was used for data collection; cell refinement was done on 25 centred reflections $\left(10.23<\theta<18.11^{\circ}\right),{ }^{3}$ data reduction: XCAD $4,{ }^{4}$ program used to solve the structure: SIR $92 ;{ }^{5}$ program used to refine structure: SHELXL97; ${ }^{6}$ software used to prepare material for publication and deposition: SHELXL97, ${ }^{6}$ PARST $95^{7}$ and WinGX. ${ }^{8}$

\section{Plant material}

Stems and leaves of $R$. echinata were collected in Ressacada, Ibirama, SC, Brazil and identified by A. Reis (Universidade Federal de Santa Catarina) and J. R. Pirani (Universidade de São Paulo). Voucher specimens [A. Reis \& M. Biavatti 2.570 (26/07/98)] were deposited in the Herbário Barbosa Rodrigues (HBR), Itajaí, Santa Catarina, Brazil.

\section{Extraction and isolation of compounds}

The dried and powdered stems $(5 \mathrm{~kg})$ and leaves $(3 \mathrm{~kg})$ were extracted with hexane and $\mathrm{MeOH}$. Successively, half part $(100.00 \mathrm{~g}$ ) of the $\mathrm{MeOH}$ stems extract was fractionated over silica gel 60 (70-230 mesh) into three fractions: $\mathrm{CH}_{2} \mathrm{Cl}_{2}$, EtOAc and $\mathrm{MeOH}$. The methanol fraction $(89 \mathrm{~g})$ was dissolved in $\mathrm{H}_{2} \mathrm{O}-\mathrm{MeOH}$ (3:7) and successively partitioned using solvents of increasing polarity (hexane, $\mathrm{CH}_{2} \mathrm{Cl}_{2}$ and EtOAc), affording the correspondent sub fractions. The $\mathrm{CH}_{2} \mathrm{Cl}_{2}$ sub fraction (2 $\mathrm{g}$ ) was chromatographed over silica gel (230-400 mesh) using as eluent $\mathrm{CH}_{2} \mathrm{Cl}_{2}$-EtOAc (9:1 and gradient) to furnish the compounds (in eluting order): maculine $(3)(36 \mathrm{mg})$, flindersiamine (4) (32 mg), kokusaginine (2) (42 mg), skimmianine (1) (29 mg), and the alkaloid 7 (10 mg).

The $\mathrm{MeOH}$ leaves extract $(100 \mathrm{~g})$ was also submitted to liquid partition with hexane, $\mathrm{CH}_{2} \mathrm{Cl}_{2}, \mathrm{EtOAc}$ and $\mathrm{MeOH}$. Column chromatography (silica gel $230-400$ mesh, hexaneacetone 7:3) of the leaves hexane fraction $(10 \mathrm{~g})$ yielded compounds $5(600 \mathrm{mg})$ and $\mathbf{6}(300 \mathrm{mg})$. All the furoquinoline alkaloids described above (except flindersiamine) were also found in the leaves extract in considerable amounts.

\section{Identification of the isolated compounds}

The isolated alkaloids skimmianine ${ }^{9}(\mathbf{1})$, kokusaginine ${ }^{10}$ (2), maculine ${ }^{9}(3)$, and flindersiamine ${ }^{11}$ (4) presented spectral data in agreement with the literature.

Flindersiamine (4) Yellow needles, mp 206-208 ${ }^{\circ}$. Crystallographic data: publication no. CCDC 151162.

2-n-Nonyl-4-quinolone ${ }^{12}$ (5) Amorphous solid, mp 74$76^{\circ}$, EIMS $m / z$ (rel. int. \%) [ $\left.\mathrm{M}^{+}\right] 271$ (10), 256 (3), 228 (5), 214 (4), 186 (11), 172 (60), 159 (100), 130 (30). ${ }^{1} \mathrm{H}$ and ${ }^{13} \mathrm{C}$ NMR Table 2.

1-Methyl-2-n-nonyl-4-quinolone ${ }^{13}$ (6) Amorphous solid, mp 71-73 ${ }^{\circ}$, EIMS m/z (rel. int. \%) [ $\left.\mathrm{M}^{+}\right] 285$ (10), 270 (3), 242 (5), 214 (4), 186 (60), 172 (100), 144 (50). ${ }^{1} \mathrm{H}$ and ${ }^{13} \mathrm{C}$ NMR: Table 2.

1-Methyl-2-phenyl-4-quinolone ${ }^{14}$ (7) Amorphous

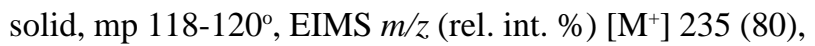


207 (100), 191 (5), 178 (8), 165 (15), 130 (10), 102 (50), 89 (30), 77 (55), 51 (50). ${ }^{1} \mathrm{H}$ and ${ }^{13} \mathrm{C}$ NMR Table 2.

\section{Fungicidal assay}

The fungus Leucoagaricus gongylophorus Singer (Rozites gongylophora Möller) was isolated from a Atta sexdens Forel nest, kept in culture media and the fungicidal activity was performed according to established protocols. ${ }^{15}$

\section{Trypanocidal activity}

The in vitro trypomastigote forms of T. cruzi ( $\mathrm{Y}$ strain) lethality assay was also performed according to established protocols. ${ }^{16}$

\section{Results and Discussion}

Compounds 1-4 were respectively identified as skimmianine, kokusaginine, maculine and flindersiamine, by comparison with the spectral data described in the literature..$^{9-11}$

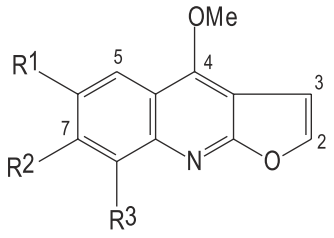

$1 \mathrm{R} 1=\mathrm{H}, \mathrm{R} 2=\mathrm{R} 3=\mathrm{OMe}$ $2 \mathrm{R}^{1}=\mathrm{R} 2=\mathrm{OMe}, \mathrm{R} 3=\mathrm{H}$ $3 \mathrm{R}^{1}=\mathrm{R} 2=\mathrm{OCH}_{2} \mathrm{O}, \mathrm{R}^{3}=\mathrm{H}$

$4 \mathrm{R}^{1}=\mathrm{R} 2=\mathrm{OCH}_{2} \mathrm{O}, \mathrm{R}^{3}=\mathrm{OMe}$

Flindersiamine (4) has a methoxy group attached to $\mathrm{C} 8$, but spectroscopic data published could not furnish clear evidence of this moiety. In an attempt to confirm the extra methoxy group position on the furoquinoline nucleus, nOe experiments were performed. According to these experiments, by irradiation on the $\mathrm{C} 4$ methoxy group only the furan $\mathrm{H} 3$ signal was enhanced. Also, when the singlet corresponding to the quinoline hydrogen was irradiated, no enhancement was observed for the methoxy group as expected. These questionable irradiation results of $\mathbf{4}$ were verified by HMBC experiments. Unexpectedly, the $\mathrm{C} 4$ methoxy group showed correlation with the quinoline hydrogen. In order to solve these unclear findings, an X-ray analysis (Figure 1) was performed to confirm the $\mathrm{C} 8$ methoxy group position.

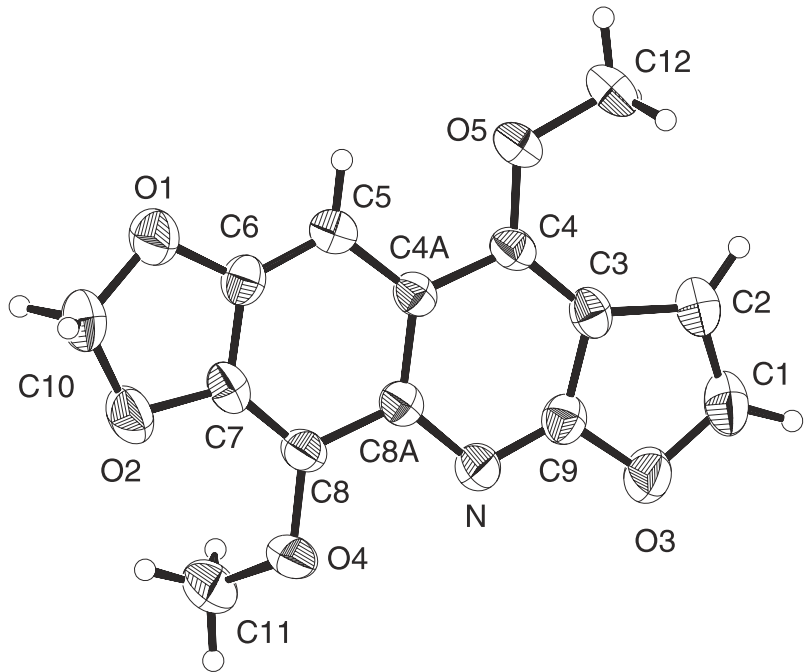

Figure 1. ZORTEP view of $\mathbf{4}$ showing crystallographic atom labelling. Ellipsoids of non- $\mathrm{H}$ atoms are drawn at $50 \%$ probability.

The molecule is planar except for $\mathrm{C} 11$, in fact the rms deviation for 16 non- $\mathrm{H}$ atoms fitted to the best least squares plane through them is of 0.026 and C11 being 1.069(3) $\AA$ out of that plane. A net of hydrogen bonds as shown in Table 3 joins the molecules in the crystal.

Special attention should be given to a C-H... interaction and following Zukerman-Schpector et al. ${ }^{17}$ this

Table 1. Evaluation of the growth inhibitory activity of crude extracts, fractions and compounds of Raulinoa echinata

\begin{tabular}{|c|c|c|c|c|c|c|}
\hline \multirow[t]{2}{*}{ Extract/fraction/ compound } & \multicolumn{6}{|c|}{$\%$ of growth inhibition of L. gongylophorus } \\
\hline & $\mu \mathrm{g} \mathrm{mL-1}$ & 50 & 100 & 250 & 500 & 1000 \\
\hline $\mathrm{MSE}^{\mathrm{a}}$ & & - & - & - & - & 80 \\
\hline Skimmianine(1) & & 60 & 80 & $\mathrm{NT}^{\mathrm{b}}$ & NT & NT \\
\hline Kokusagine (2) & & 20 & 100 & NT & NT & NT \\
\hline Maculine (3) & & 10 & 50 & NT & NT & NT \\
\hline Flindersiamine (4) & & - & 50 & NT & NT & NT \\
\hline $\mathrm{MLE}^{\mathrm{c}}$ & & - & - & - & - & 80 \\
\hline MLE (hexane fraction) & & & & & 80 & 100 \\
\hline 2- $n$-Nonyl-4-quinolone (5) & & 20 & 50 & NT & NT & NT \\
\hline 1-Methyl-2-n-nonyl-4-quinolone $(\mathbf{6})$ & & - & - & - & - & - \\
\hline 1-methyl-2-phenyl-4-quinolone (7) & & NT & NT & NT & NT & NT \\
\hline
\end{tabular}

${ }^{a}$ MSE: methanol stems extract, ${ }^{b} \mathrm{NT}$ : not tested, ${ }^{\mathrm{c}} \mathrm{MLE}$ : methanol leaves extract 
Table 2. ${ }^{1} \mathrm{H}$ and ${ }^{13} \mathrm{C}$ NMR chemical shift data for compounds 5, 6 and 7.

\begin{tabular}{|c|c|c|c|c|c|c|}
\hline \multirow[t]{2}{*}{ Position } & \multicolumn{3}{|c|}{$\delta_{\mathrm{H}}$} & \multicolumn{3}{|c|}{$\delta_{\mathrm{C}}$} \\
\hline & 5 & 6 & 7 & 5 & 6 & 7 \\
\hline 2 & & & & 155.1 & 154.7 & 154.8 \\
\hline 3 & $6.23 \mathrm{~s}$ & $6.22 \mathrm{~s}$ & $6.31 \mathrm{~s}$ & 108.2 & 109.8 & 112.7 \\
\hline 4 & & & & 178.9 & 177.8 & 177.6 \\
\hline 5 & $8.36 \mathrm{dd}(8.0 ; 1.2)$ & $8.41 \mathrm{dd}(8.0 ; 1.5)$ & $8.51 \mathrm{dd}(8.0 ; 1.4)$ & 125.3 & 126.3 & 126.8 \\
\hline 6 & $7.32 \mathrm{dt}(8.0 ; 0.9)$ & $7.35 \mathrm{dt}(7.5 ; 1.0)$ & 7.45 br t (1.0) & 123.5 & 124.8 & 123.8 \\
\hline 7 & $7.58 \mathrm{dt}(8.0 ; 1.5)$ & $7.63 \mathrm{dt}(7.7 ; 1.6)$ & $7.73 \mathrm{dt}(7.8 ; 1.6)$ & 131.7 & 133.2 & 132.3 \\
\hline 8 & $7.72 \mathrm{~d}(8.0)$ & $7.48 \mathrm{~d}(8.6)$ & $7.57 \mathrm{~d}(8.5)$ & 118.4 & 115.8 & 115.9 \\
\hline 9 & & & & 140.6 & 141.4 & 141.9 \\
\hline 10 & & & & 125.0 & 126.3 & 126.8 \\
\hline 1 , & $2.68 \mathrm{t}(7.8)$ & $2.69 \mathrm{t}(7.9)$ & & 34.4 & 31.8 & 135.9 \\
\hline 2 & 1.71 pent $(7.8)$ & 1.65 pent $(7.3)$ & $7.42 \mathrm{~m}$ & 29.4 & 29.3 & 128.5 \\
\hline $3^{\prime}$ & 1.17 br s & 1.24 br s & $7.52 \mathrm{~m}$ & 31.8 & 29.2 & 128.8 \\
\hline 4 ' & 1.17 br s & 1.24 br s & $7.52 \mathrm{~m}$ & 29.2 & 29.2 & 129.6 \\
\hline 5, & $1.17 \mathrm{br} \mathrm{s}$ & $1.24 \mathrm{br} \mathrm{s}$ & $7.52 \mathrm{~m}$ & 29.2 & 29.2 & 128.8 \\
\hline 6 ' & $1.17 \mathrm{br} \mathrm{s}$ & $1.24 \mathrm{br} \mathrm{s}$ & $7.42 \mathrm{~m}$ & 29.2 & 29.2 & 128.5 \\
\hline 7 & 1.17 br s & 1.24 br s & & 29.2 & 28.6 & \\
\hline 8 & 1.17 br s & 1.24 br s & & 22.6 & 22.6 & \\
\hline 9' & $0.83 \mathrm{t}(7.1)$ & $0.84 \mathrm{t}(7.0)$ & & 14.1 & 14.1 & \\
\hline $\mathrm{N}-\mathrm{H}$ & $11.88 \mathrm{br} \mathrm{s}$ & & & & & \\
\hline $\mathrm{N}-\mathrm{Me}$ & & $3.71 \mathrm{~s}$ & $3.62 \mathrm{~s}$ & & 35.2 & 37.3 \\
\hline
\end{tabular}

interaction is characterized by three parameters, the $\mathrm{H} 11 \mathrm{C} . . . \mathrm{Cg}^{\mathrm{i}}(\mathrm{Cg}$ is the centroid of the O3-C1-C2-C3-C9 ring) distance of $3.39 \AA$, the $\mathrm{C} 11-\mathrm{H} 11 \mathrm{C} . . . \mathrm{Cg}$ angle of $128^{\circ}$ and the angle between the $\mathrm{H} . . . \mathrm{Cg}^{\mathrm{i}}$ vector and the plane of the ring of $92^{\circ}$. (symmetry operation: $\mathrm{i}=1-\mathrm{x},-0.5+\mathrm{y}, 1.5-\mathrm{z}$ ).

Whether all the cited interactions are true hydrogen bonds is difficult to assert, because as pointed out by Cotton et al. ${ }^{18}$ "...the field is getting muddier and muddier as the definition of a hydrogen bond is relaxed." In any case they are worth to be taken into account.

The crystallographic data obtained for the alkaloid 4 confirmed the previous HMBC spectroscopic attributions, but not the results obtained by nOe experiments.

The structures of compounds $\mathbf{5 , 6}$ and $\mathbf{7}$ were elucidated on the basis of ${ }^{1} \mathrm{H}$ NMR and EIMS spectra and carbon attributions were made by HMBC and HSQC correlation spectra. Data are presented on Table 2.

Crude extracts of leaves and stems as well as fractions of $R$. echinata showed good inhibitory activity on $L$. gongylophorus growth. Among the isolated compounds of these fractions, each of the alkaloids 1-5 maintained or showed higher inhibition of the fungal growth at $100 \mathrm{mg} \mathrm{mL}^{-1}$ (Table 1), compared with the original extracts. Contrary to the expectations, at a $50 \mu \mathrm{g} \mathrm{mL}^{-1}$ dose the inhibitory effect was quite strongly reduced. In general, furoquinoline alkaloids showed higher activity than quinolones. Probably, the activity demonstrated by the methanol extract of leaves (fraction hexane) is due to the high concentration of total alkaloids, both furoquinoline and quinolone derivatives.

Only the quinolinone alkaloids $\mathbf{5}$ and $\mathbf{6}$ displayed some
Table 3. Hydrogen bonds parameters of crystalline compound 4. Symmetry operations: i) $2-\mathrm{x}, 0.5+\mathrm{y}, 1.5-\mathrm{z}$; ii) $\mathrm{x},-0.5-\mathrm{y}, 0.5+\mathrm{z}$; iii) $\mathrm{x}, \mathrm{y}, \mathrm{z}$; iv) $\mathrm{x},-0.5-\mathrm{y}-0.5+\mathrm{z} ; \mathrm{v}) \mathrm{x}, 0.5-\mathrm{y}, 0.5+\mathrm{z}$.

\begin{tabular}{cccc}
\hline D-H...A & H...A/A & D...A/A & D-H...A/ ${ }^{\circ}$ \\
\hline $\mathrm{C} 1-\mathrm{H} 1 \ldots \mathrm{N}^{\mathrm{i}}$ & 2.96 & $3.429(3)$ & 147 \\
$\mathrm{C} 10-\mathrm{H} 10 \ldots \mathrm{N}^{\mathrm{ii}}$ & 2.49 & $3.421(3)$ & 160 \\
$\mathrm{C} 11-\mathrm{H} 11 \mathrm{~A} \ldots 2^{\mathrm{ii}}$ & 2.90 & $3.53(3)$ & 124 \\
$\mathrm{C} 11-\mathrm{H} 11 \mathrm{~B} \ldots 1^{\mathrm{iv}}$ & 2.60 & $3.201(3)$ & 121 \\
$\mathrm{C} 12-\mathrm{H} 12 \mathrm{~B} \ldots 3^{\mathrm{v}}$ & 2.89 & $3.680(3)$ & 141 \\
\hline
\end{tabular}

moderate activity on trypomastigote forms (Y strain) of $T$. cruzi with $\mathrm{IC}_{50}$ of 134.9 and $100.9 \mu \mathrm{g} \mathrm{mL}^{-1}$ respectively.

Fungicidal activities have been described for these alkaloids against plant pathogens Cladosporium cucumerinum $^{19}$ and Phytophthora spp..$^{20} 4$-Quinolones containing long alkyl chains at C-2 were first obtained from microorganisms (from Pseudomonas, also called pseudans ${ }^{21}$ ) and have been also isolated from rutaceous genera, mainly Evodia ${ }^{22}$ Boronia, ${ }^{23}$ Ruta ${ }^{13}$ and Esenbeckia. ${ }^{24}$ Species from the former genus are used in Chinese herbal medicine and the isolated alkaloids have demonstrated inhibitory activity against the bacteria Helicobacter pilori. ${ }^{25,26}$

Furoquinoline alkaloids have also demonstrated in vitro activity against Leishmania spp and Plasmodium falciparum. $^{27,28}$

\section{Acknowledgements}

We wish to thank Prof. A. Reis for collecting and identifying and Prof. J. R. Pirani for identifying the plant 
material, CAPES/PIDCT and UNIVALI for Ph.D. sponsorship of MWB and FAPESP, CNPq/PRONEX, MCT/ FINEP for financial support. The $\mathrm{X}$-ray facilities at Instituto de Química, USP was installed with a grant from FAPESP (94/2061-4).

Supplementary Information - Supplementary Crystallographic data have been deposited with the Cambridge Crystallographic Data Centre as supplementary publication no. CCDC 151162. Copies of available material can be obtained, free of charge on application to the Director, CCDC, 12 Union Road, Cambridge CH2 1EZ, UK (fax: +44-1223-336-033 or e-mail: deposit@ccdc.cam.ac.uk or http://www.ccdc.cam.ac.uk)

\section{References}

1. Kaastra, R.C.; Flora Neotropica, monograph no 33, 1982.

2. Biavatti, M.W.; Vieira, P.C.; Silva, M.F.G.F.da; Fernandes, J.B.; Albuquerque, S.; Magalhães, C.M.I.; Pagnocca, F.C.; Phytomedicine 2001, 8, 121.

3. CAD-4 Software; Version 5.0 Enraf-Nonius, Delft; The Netherlands, 1989.

4. Harms, K.; Wocadlo, S.; XCAD4; University of Marburg; Germany, 1995.

5. Altomare, A.; Cascarano, G.; Giacovazzo, C.; Guagliardi, A.; SIR92; J. Appl. Cryst. 1993, 26, 343.

6. Sheldrick, G.M.; SHELXL97; University of Göttingen; Germany, 1997.

7. Nardelli, M.; PARST95; J. Appl. Cryst. 1995, 28, 659.

8. Farrugia, L.J.; WinGX; University of Glasgow; Scotland, 1998.

9. Robertson, A.V.; Aust. J. Chem. 1963, 16, 451.

10. Khalid, S.A.; Waterman, P.G.; Phytochemistry 1981, 20, 2761.

11. Ayafor, J.F.; Sondengam, B.L.; Kimbu, S.F.; Tsamo, E.; Connolly, J.D.; Phytochemistry 1982, 21, 2602.

12. Kan-Fan, C.; Das, B. C.; Boiteau, P.; Potier, P.; Phytochemistry 1970, 9, 1283.
13. Grundon, M.F.; Okely, H.M.; Phytochemistry 1979, 18, 1768.

14. Akhmedzhanova, V.I.; Bessonova, I.A.; Yunusov, S.Y.; Chem. Nat. Compd. 1986, 22, 78.

15. Pagnocca, F.C.; Silva, O.A.; Hebling-Beraldo, M.J.; Bueno, O.C.; Fernandes, J.B.; Vieira, P.C.; Bull. Entomol. Res. 1990, 80, 349.

16. Alves, T.M.D.; Alves, R.D.; Romanha, A.J.; dos Santos, M.H.; Nagem, T.J.; Zani, C.L.; J. Nat. Prod. 1999, 62, 369.

17. Zukerman-Schpector, J.; Camillo, R.L.; Comasseto, J.V.; Santos R.A.; Caracelli, I.; Acta Crystallogr. 1999, C55, 1577.

18. Cotton, F.A.; Daniels, L.M.; Jordan, G.T.; Murillo, C.A.; J. Chem. Soc. Chem. Commun. 1997, 17, 1673.

19. Zhao, W.; Wolfender, J.L.; Hostettmann, K.; Xu, R.; Qin, G.; Phytochemistry 1998, 47, 7.

20. Moon, S.S.; Kang, P.M.; Park, K.S.; Kim, C.H.; Phytochemistry 1996, 42, 365.

21. Reisch, J.; Rózsa, Z.; Szendrei, K.; Körösi, J.; Phytochemistry 1975, 14, 840 .

22. Tang, Y.Q.; Feng, X.Z.; Huang, L.; Phytochemistry 1996, 43, 719.

23. Sarker, S.D.; Armstrong, J.A.; Waterman, P.G.; Phytochemistry 1995, 39, 801.

24. Guilhon, G.M.S.P.; Baetas, A.C.S.; Maia, J.G.S.; Conserva, L.M.; Phytochemistry 1994, 37, 1193.

25. Rho, T.C.; Bae, E.A.; Kim, D.H.; Oh, W.K.; Kim, B.Y.; Ahn, J.S.; Lee, H.S.; Biol. Pharm. Bull. 1999, 22, 1141.

26. Hamasaki N.; Ishii, E.; Tominaga, K.; Tezuka, Y.; Nagaoka, T.; Kadota, S.; Kuroki, T.; Yano, I.; Microbiol. Immun. 2000, 44, 9.

27. Fournet, A.; Barrios, A.A.; Munoz, V.; Hocquemiller, R.; Cave, A.; Bruneton, J.; Antimicrob. Agents Chemother. 1993, 37, 859.

28. Basco, L.K.; Mitaku, S.; Skaltsounis, A.L.; Ravelomanantsoa, N., Tillequin, F., Koch, M., Le Bras, J.; Antimicrob. Agents Chemother. 1994, 38, 1169.

Received: November 23, 2000

Published on the web: November 8, 2001

FAPESP helped in meeting the publication costs of this article. 